in the amount of indican in the urine; and the same is true of acute or chronic diffise parenchymatons nephritis. On the other hand, in four cases of grinular kilney, a large anount of indican was found to be excreted. In chlorosis, in the various forms of leukcemia aud pseudo-leukcemia, and in progressive pernicions anremia, there is a modcrate increase in the indican excretion; but even when the anount of wasting and the loss of strength in pernicious anxmia exceel thosc in cancer of the stomach, as far as Professor Senator's observations go, the excretion never attains the same proportions as in the latter disease. The diagnostic rahe of this fact, if confirmed by other observers, is self-evilent. Intestinal obstruction rependent on mechanical causes, or on intussusception, appears (in the absence of canc(r or peritonitis) not to cumse much excretion of indiean. In some enses where there is an abnormal excretion of indican, there is a simultaneous increase in the anount of lime in the urine. 'This is the case in phthisis, eren where very little food is taken, and in spite of the presence of diarrhea. It also oc'urs in children with multiple swellings of the grlands and with rickets. In acute febrile diseases, however, such as pneumonia or typhoirl fever, the excretion of lime and that of indican appear to diverge from one another, that of the forner being diminished, and that of the latter inerensed. In pleurisy with eflision alone has Professor Senator sereral times observed that there was an increased excretion of lime, notwithstanding the presence of ferer.

The method alopted in testing for indican in the above researeh was the following:-The urine is, if necessary, to be freed from albumen in the usual way, and ten to fifteen cubic centimetres are to be mixed with an equal quantity of fuming lydrochloric acid in a rather large test-glass. A concentrated solution of chloride of caleium is then to be added gradually, drop by drop, until the blue color of indigo is filly developed, and the whole is then to be shaken up with elloroform. "The latter takes up the freshly precipitated indigo, and sinks with it to the bottom of the glass, wlere the amount can be estimated with a little practice, in tlie same way as alloumen is usually estinated, but far more aceurately. 'This remark applies to pale urines (which, as a rule, are the richest in incliean). Highly pigmented urines must be first decolourized by acetate of lead, avoiding an excess of the latter reagent before applying the indiean tests.-Med. 'Times and Gaz., Sept. 22, 1877.

\title{
Diminution of the Acidity of the Gastric Juice in Febrile Conditions.
}

An interesting illustration of the relation of the hydrochloric acid of gastric juice to the febrile process is afforded by a case reported by Dr. VON DEN VELDEN, assistant to P'rofessor Kussmaul, at Strasburg, in the Berl. Klin. IVoch. (No. 42, 1877). The patient, a man of sixty, had suffercd from gastric syinptoms for about ten ycars, which latterly assuined the character of those of dilatation of the stomach, pain in the epigastrium, repeated vomiting, etc., which reduced lis strengtl to such a degree that he was obliged to enter the hospital for relicf. He was athitted on February 27,1877 , and treated with the stomachpuinp with great benefit, and the disappearance of the romiting. The fluid which was punped out (in the morning betore breakfust) was generally quite clcar, and ranged in quantity between 100 and 700 cubic centimetres. At first it contained sarcine and torula, with abnndance of peptones, aud a gradually dininishing amount of undigested food. The percentage of hydrochloric acid was determined by Resch's colour test (described in the Zeitschrift für Phys. Chemie, Bd. i. 3), and varied between $0.025,0.03,0.05,0.13,0.15,0.16$, and in one instance 0.3 per cent. In May, when the patient's improvement had become so great that he was about to leave the hospital, he began to suffer from diarrliœa, and on Jnnc 7, headache, fever, and general malaise ushered in an attack of typhoid fever 
(souree not stated), which ran a normal course, and terminated about the twentysecond day. During the attack the stomach-pump was used daily before breakfast, and the liquid removed carefully examined. In quantity it was less than previously, and scarcely reached 100 eubie centimetres. The main difference in its composition revealed by analysis was the absence of free hydrochloric acid, although its reaction was faintly acirl, probably from the presence of lactic or acetie acid. A flake of fibrin remained quite undigested whilst in some of the filtered linguid in the cold; whereas the addition of an eqmal volume of 0.2 per cent. dilute hydroehloric acid caused its rapirl disappearance. On the eessation of fever, on Jume 7, Dr. Von den Velden naturally expected that hydrochlorie acid wonla again be found in the gastrie liquid. He had, lowever, to wait until the eighth day after the temperatnre had becone normal before traccs of it reappeared. On the ninth day 0.08 per eent. was detected, and from this time onwards the pereentage ranged between the limits mentioned above. It might be objected that since in this ease the gastrie contents were renoved before food had been ingested, the absence of acid might depend on the absence of a stimulus to its secretion; but this objection fails, because the patient happened one norning to breakfast before being pumped, and still not a trace of frec hychochloric acil was present. The absence of acid was also not due to the patient's diet during the periok of fever, for the latter consisted, inter alia, of milk, boullon containing eggs, and other nitrogenized substances, in the presence of which acid juice wonld normally be secreted. Lastly, there was no increased secretion of alkaline inneus which would mask the firee acid by nentralizing it as soon as secreted. 'This case confirms the observations of Pavy, Hoppe-Seyler, Manassein, Lenlu, Uffelmamn, and others, that it is the acid, and not the pepsin, of the gastrie juice which suffer's diminution in fever, and it sngrests the more extensive use of lydrochloric acid during the period of elevated temperature.-Med. Times and Gaz., Nov. 10,1877 .

\section{Salicine in Rhenmatism.}

Mr. Samson Gemilil aud Mr. Frank Shrakriz contribnte a paper on this subject to the Glasgow Medical Journal (Oct. 187\%), in which they give the following conclusions :-

1. In acnte febrile artienlar rhcumatism, free from all complications, salicylate of soda is the most powerful therapentie ineans which we possess; it eures more rapidly than any other.

2. It is imposiblole to assign to the treatment a uniform dnration of days.

3. It does not prevent the earliae, pulmonary, and eerchrel complications of acute rheumatism ; and where these exist prior to the treatment, it has no eflect on them.

4. In spite of its antipyretic properties, it does not hinder the ascent of the temperature, which announces the advent of visceral complications.

5. In acute rhemutism, with slight eomplications, it is well to push the salicylate for its antipyretic and analgesic effects, but the use of revulsives should not be forgottell.

6. In acute rleunatism, with grave complications, it is well not to rely on the salicylate alone, but also to have recourse to other medicines.

\section{Etiology of 'Typhoid Fever.}

M. CH. Bouchard real before the International Medical Congress, at Geneva, Sept. 12th, 1877, an interesting report on this subject, which is published in Revue Mensuelle de Méd. et de Chir. for Nov. The following are his conelusions :- 